コストとのギャッブは大きく，近い将来に体系化 されるであろう先端技術を駆使した場合のコスト (可能性としてのコスト) でも，その差は埋めき れない。したがって，ここでは国民世論の動向に かかわる政治的経済的問題が介在せざるを得ない のであり，前提条件に関する地域合意を困難にす る。

第 2 に, 地域農業構造の再編に対しては農協の 果たす役割が大きく，本ビジョンでもこれを基本 的な単位として位置づけているが, 本市の15の農 協は大小さまざまであり，すべての農協が期待ど おりの機能を発揮するとは思われない。この点か ら, 将来の内外環境の変化に適応しうる農協の適 正規模・管理方式のあり方の追求が必要となる。

第 3 に，農村社会構造の再編に関して，「里づ
くり」を提起したが, これは前述の混住化社会の コミュニティー形成の原理・手順にかかわる問題 であり，今後，この点についてのより実証的な解 明が必要である。

第 4 に，自然資源の保全や美しい景観の創出 は, 都市近郊の農村計画でも欠かせない要素であ るが，今回のようにやや広域でビジョンを描く場 合は一般的方向づけですむとしても，特定の空間 を具体的にデザインする場合には，より客観的な 評価基準・指標が求められるであろう。

第 5 に，本ビジョンでは地域の生産資源に関す る情報リストの整備の必要性についてふれている が，全体的な地域情報システムを構想するまでに 至っていない。この点も, 今後の課題である。

〔報告 II

\title{
農山村地域における農村計画的課題
}

1. はじめに

本稿は農業土木分野からみた農村計画的課題を 考えることにあるが，今日の農業と農村をめぐる 内外の厳しい要請と期待は農村計画的対応を迫っ ている。しかし，農山村における土地利用の再編 は高度な生産技術が発揮される農用地をいかに確 保し，整備・保全していくべきかの問題を中心に して展開されるべきと考えここでは農山村を今 日話題の中山間地域とみなし，そのなかでも溜池 潅溉地域（以下溜池地域）の圃場整備をとりあげ て，土地利用を計画的に再編する場合の問題と課 題を考えてみたい。

\section{2. 農業土木の動向}

農業土木学会では21世紀を迎えるにあたり，農 業土木学の将来ビジョンを検討し，その報告を昨 年 9 月に「豊かで美しい国土・農村空間の創出」 ${ }^{1}$
香川大学農学部 森 下 一 男

と題して刊行した。学会も農業のみならず, 国土 - 農村空間に対して国民全体が求めているもの, あるいは, 今後より強く求められるであろうこと に対応して進もうとしている。

それで，農業土木事業も望ましい農村空間の創 出に向けて新たに展開しようとし，従来進めてき た潅溉排水, 煵場整備, 農用地開発, 農道整備, 農地保全・防災, 土地改良施設の維持管理, 農村 環境整備，等の諸事業はそのための基幹作りであ ると位置付け, 今後とも一層の事業実施が必要で あるとしている。

ただ上記報告によれば，従来の事業実施が全国 一律的に画一的に実施されてきた傾向があると し, 今後は各地域の各々の特性に即し個性的な村 つくり，地域振興が図れるよう，これまで以上に 地域の実情を吟味し，画一的な適用を避け適切な 事業展開を図る必要があるとしている。

たとえば，農地の整備について目標水準に達し 
ている整備済みの農地は昭和62年度末で水田約 125万ha（水田全体の $43 \%$ ), 畑 112 万ha（畑全体 の46\%) であり，田畑とも整備率は50\%に達して いない。そのため, 今後の整備に当たっては $30 \mathrm{a}$ の現行標染区画にこだわることなく，条件の許す 限り大区画の固場に整備すべきであり，一方，集 落周辺に自家飯米の生産に適した圈場や家庭菜園 を配置し、また, 地形条件の厳しい所では, 極力 地形にマッチした区画を採用すべきであるとし， キメ細かい対応が必要であるとしている。

そこで,ここでは今後の農村地域の土地利用を 計画的に再編していくための課題を考えるため に, 地形条件に制䄪され，しかも土地利用と水利 用の錯綜している溜池地域の圃場整備を, 用水の 受益地区である池掛りの再編問題を中心としてと りあげてみたい。

\section{3. 中山間地域の團場整備}

中山間地域とは「地形的にまとまった平坦な耕
地が少なく傾斜地と背後の山林から構成され, 释 済的に農林水産業を核として産業が構成されてい る地域」であり，まとまった平坦な耕地の多い地 域に比較して，規模拡大等による農業生産性の向 上を図るうえで不利な条件の多い地域である2りと されているが，まず戋場整備の事例をみてみた w。

\section{（1）溜池地域における戋場整備の事例}

香川県寒川町石井集落は昭和 53 年 57 年度にか けて団体営戋場整備事業を実施した。事業地区面 積32haであるが, 石井集落の受益は約20haであ り，農家戸数は42戸で，非農家が 8 戸ある。集落 は山地から平坦地の移行部に立地し, 整備地区の 地形勾配は $1 / 15$ 1 / 80である。図 1 に示した ように石井集落の関係の溜池は15ケ所あり,この うち整備された池掛りは石井集落の属地内の 6 . 大池掛り (20.6ha), 13. 奥谷池掛り (2.5ha), 10. 摺鉢池掛り（0.4ha）, の三つの池掛りのほとんど

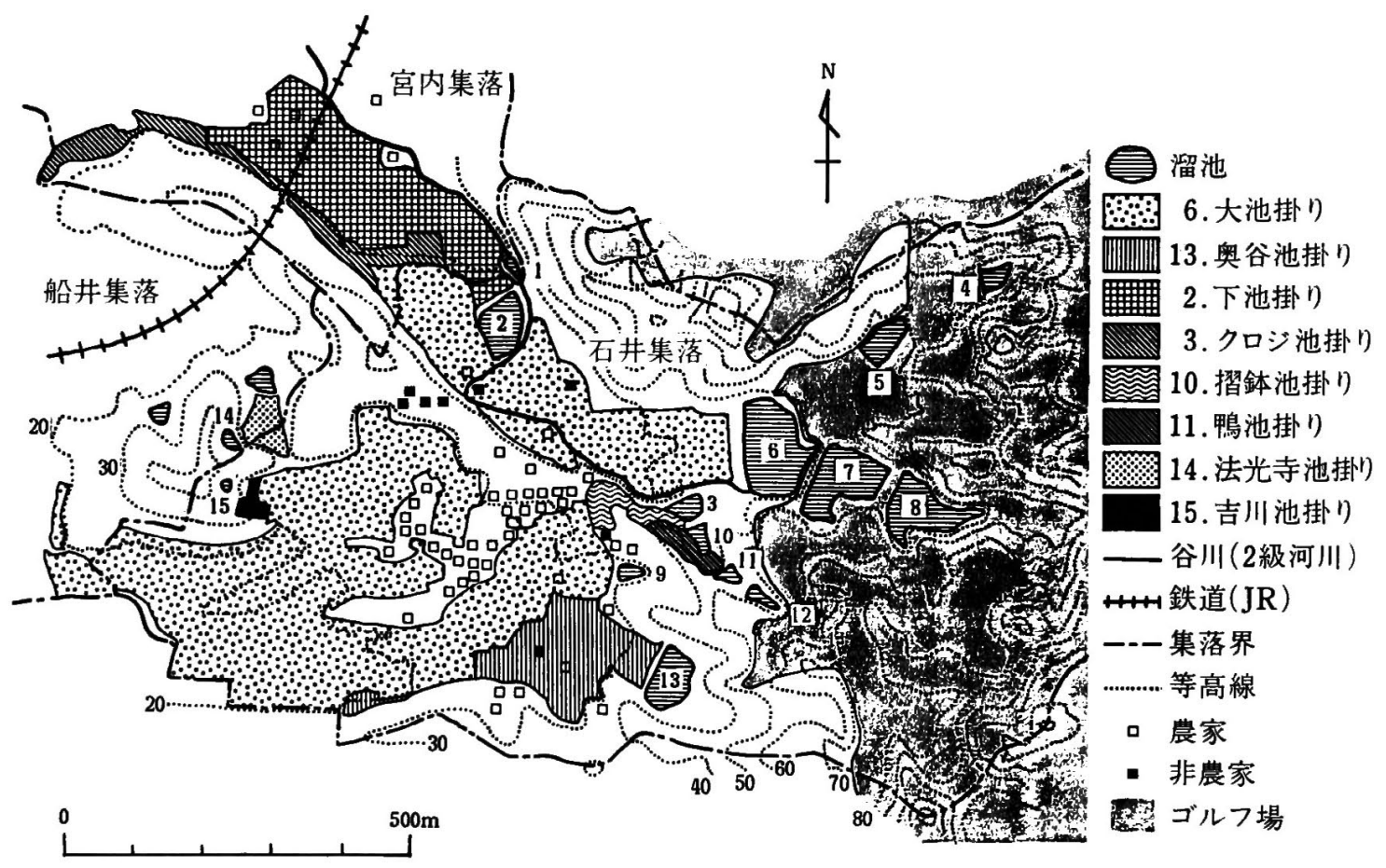

図 1 石井集落における固場整備前の池掛り図 
と,隣接の宮内集落に属す 2.下池掛り (4.1ha),

3.クロジ池掛り（1.4ha）のうち，鉄道より東側 の区域 (4.0ha) であり，宮内集落内の整備地区 には石井集落の出作地があった。

石井集落は圈場整備によって, 用水路をパイプ 眍管し，パイプは溜池の6. 大池 $(3$ 万 $\mathrm{t})$ と13. 奥谷地（7千 $\mathrm{t}$ ) に直結した。これにより各围場 は溜池と連結したのみならず，两池も5 $\mathrm{m}$ の高低 差を利用して，大池から奥谷池に送水することが 可能になり，溜池もパイプを介して連結し，連係 して運用することが可能になった。

石井集落の出作地のあった 2.下池掛りは宮内 集落と耕作が混在しており, 整備面積は3.3ha あ った。整㖮を機会にして下池を廃止しょうとした が賛同が得られず，石井集落の出作面積分 (1.45 ha）と宮内集落の賛同面積分 (0.86ha) だけ下池 の水面51 a のうち29 a を埋立てて溜池を廃止に し，整備後は 6.大池掛りに編入された。また， 3.クロジ池掛りは溜池と池掛りが離れており，水 路を 6.大池掛りと共用していたため夜間しか利 用できず，不便であった。そのため整備前には池
掛りの下流にあたる鉄道より西側の宮内集落の耕 作地では別途地下水を汲み上げポンプ潅溉を行 なっていた。鉄道より東側の石井集落の耕作地 (0.72ha）だけが溜池に依存していたが，整備を 機会に6.大池掛りに編入された。こうして，石 井集落の池掛りは固場整備を機会に統合された。

(図 2 参照)

この集落の用水利用については，用水が十分で なかったため水田への配水は水引き役が一切の権 限をもち, 各農家は自分の水田へ自分で水を入れ ることができなかった。遠い昔はいざ知らず，水 引き役は専任ではなく，昭和30年前より農家の耕 作反別の順による輪番制になっていた。水引き役 には日当があり，昭和54年当時4000円であった。 溜池または水路の改修がない場合には，水引き役 の日当が事実上の水利費になるが、昭和 54 年で反 当り 400円，前年の53年は2000円であり，水利費 はその年々の溜池貯留状況, 潅涀期の降雨によっ て変動している。しかし，昭和57年に香川用水を 6.大池までポンプアップすることになり，用水量 が増強され，水引き役による配水は廃止された。

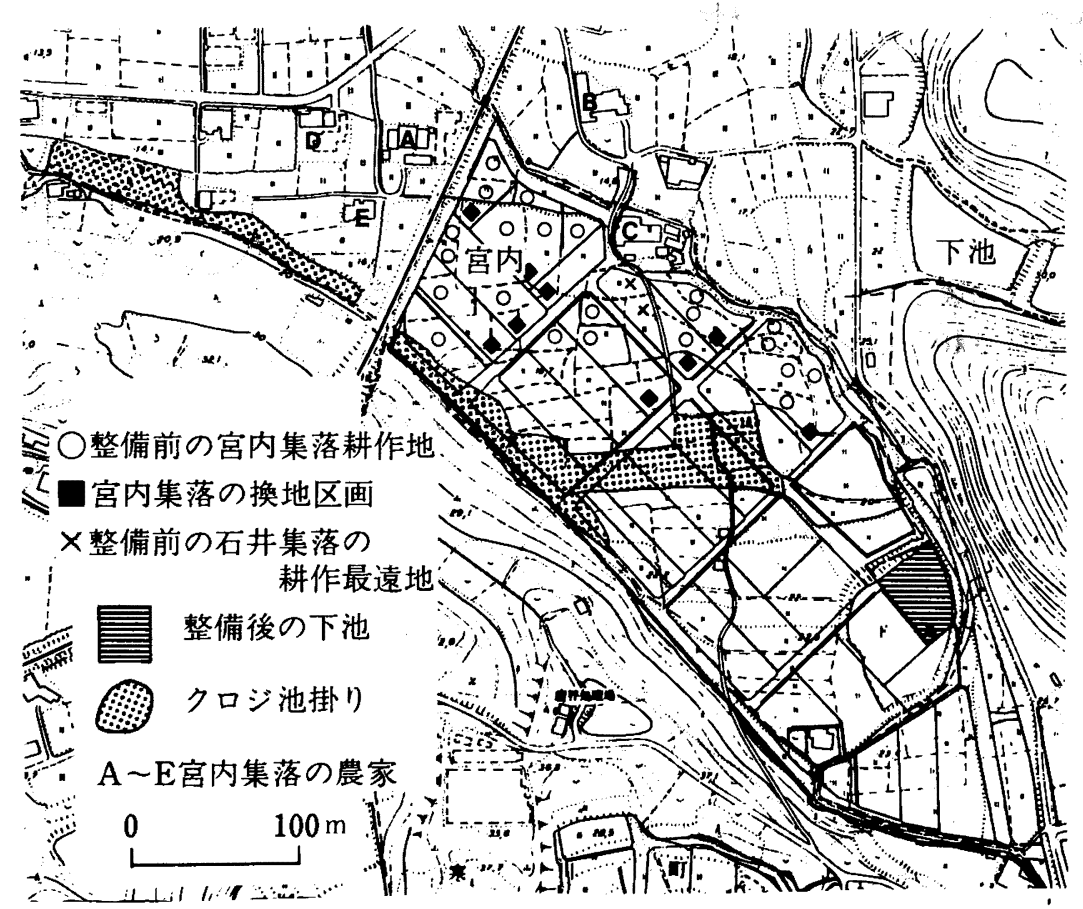

図 2 圃場整備による下池掛りとクロジ池掛りの再編 
ポンプの電気料が反当り1500円，香川用水の維持 管理費が反当り650円となり，計約 2000 円が経常 経費であるが，水引き役の水利費がポンプの電気 料に代っている。

池掛りの維持管理組織，すなわち，池掛りの耕 作者による水利団体は，当初は池掛りごとに成立 しているものだが, 石井集落では戦後 6.大池掛 り，13．奥谷池掛り，10．摺鉢池掛りが大池水利 組合（申合せ組合）に合併しており，煵場整備に よって隣接集落の出作地も大池掛りに統合され， 関係者も大池水利組合に加入した。水利組合は自 治会とは別組織になっているが, 石井集落の農家 による水利団体として再編成された。

このように, 石井集落では围場整㣁によって池 掛りが再編され，溜池・水路の維持管理も用水管 理も大池水利組合に一元化されることになり，耕 作区域と池脚りと集落組織が一体化することにな った。

\section{（2）溜池地域の圃場整備}

溜池地域では用水源である溜池とその受益地区 が一体的に意識され，その受益地区は特定の溜池 を用水源にしているという意味から，池掛り地区 として識別され，ただ単に池掛りと呼ばれること が多い。すなわち，池掛りとは特定の溜池を用水 源にもつ水田の集合であり，一定の広がりをもつ 領域である。

池掛りが一定の領域として識別されるのは，受 益者によって構成される維持管理組織の管轄領域 でもあるためであり，そこでは溜池の貯水量が一 定であるために，限られた用水を公平に配水する ために受益者による用水の維持管理組織が一体化 して形成されており，緻密な水利慣行が今日まで 存続している。

すなわち, 溜池が用水源として独立し, 溜池を 管理する組織が明確に限定され，池掛りが他の用 水系統から独立し, 用水の公平な配水が池掛りで 完結することから, 溜池は相対的に独立した水源 施設であり，完結した自立性の強い管理組織を生 み出す物的基盤になっている ${ }^{3)}$ ，と指摘される所 以である。

池掛りは用水源である特定の溜池と, それによ
って潅溉されるということ，並びに潅溉の対象と なる水田の三要素によって構成され，施設として みると，特定の溜池・潅溉水路・國場が相互に密 接なつながりをもち, 池掛りの規模は溜池販水量 の大小によって規定され，しかも，地形条件によ って制約されている。

こうした溜池貯水量や地形条件に制䄪されてい る池掛りで圃場整備を行なう場合に問題となるの は整備によって池掛りをどのように再現するかと いうことである。用水が不足する場合には用水源 の開発問題とも関係し，また潅溉水路を管水路に するか, 開水路にするかの問題も池掛りの変化に 影響する。このように問題の対処の仕方によっ て，池掛り面積，池掛り区域に影響を及はす。し かも，池掛りと一体化している維持管理組織をど うするかの問題も関係し，溜池地域における戋場 整備は池掛りの三要素の各要素の在り方に加え, 維持管理組織の在り方も関係し，多様化する要因 をはらんでいる。

さらに，一つの池掛りから一定の流域に目を向 けると，溜池地域は用水不足を解消するための用 水源の開発の歴史がそれぞれの溜池の築造に反映 されており，事例地区の石井集落では重ね池がみ られる。また，小河川から水路によって用水を補 給している場合もあり，溜池が連合して補給用の 溜池を設けている場合もある。溜池施設には用水 源を確保してきた歴史的な経緯が反映し，用水を 確保する形態が極度に発達している。

そのため, 溜池築造の歴史は同時に池掛りの形 成に反映しており，各々の池掛りは自立性と完結 性を有しながら，池掛りは互に接し合って，連担 している。池掛りが上流下流の位置関係にあれ ば，上流側の池掛りは下流に位置する池掛りの集 水域になっており, 用水の反復利用が繰り返さ れ，池掛りが連なっている。したがって，一定の 流域の水田は複数の池掛りから構成され，また池 掛り区域によって区分されることが分る。そのた め, 溜池地域における粗場整備は一定の流域全体 に影響を及ほさずにはいない。その点では，石井 集落の事例は小流域の単純な事例であったといえ よう。 
(3) 池掛りの統合

池掛りの大きさには数百へクタールから数千へ タタールにも達する大規模なものもあるが，その ような場合には㖘業水利組織も土地改良区として 組織化され，水利施設に応じた組織が重層的に構 成されているが，ここで問題にするのは，最終の 溜池から固場に配水する場合での末端の維持管理 組織が形成されている池掛りである。先にみた石 井集落の水利組合は末端の維持管理組織とみるこ とができる。

池掛りの統合には二つの形態があり，ひとつは 用水源が一箇所になって池掛りが統合される場合 であり，もう一つは複数の池掛りを一元的に管轄 する維持管理組織が形成される場合である。前者 は地形条件，また水路施設条件によって左右され る。後者は地形的にまとまりのある地域あるいは 流域を単位に形成される。

ここで関係してくるのは，池掛りと一体化して いる維持管理組織である。池卦りが集落の属地領 域より小さい場合には，石井集落のように集落の 属地領域で池掛りが統合されやすい。その理由は 耕地が地掛りことに分散し，農家が複数の池掛り に関係しているため，固場整備を機会にして耕地 の集団化を図ろうとするためであり，また，水管 理労力面では専任の水引き役が得られなくなって おり，農家もできるだけ関係の池掛りを少なくし て，水管理労力を削減したく考えているためであ る。さらに，新しく形成される池脚りからみる と，将来の維持管理を考えた場合にできるだけ受 益面積が多い方がよいと考えていることがある。

一方, 池掛りが集落の属地領域よりもおおきい 場合には，数集落か旧村が連合して複数の池掛り を一元的に管轄する維持管理組織が形成される。 実際に当面するのは，複数集落の耕作区域と複数 の池掛りが錯綜している場合とか，あるいは，大 規模な围場整備に伴って広域的に溜池の運用形態 を再編するような場合に池掛りの統合が生じてい る。これ以外の場合では, 用水路をパイプライン にして，複数の池掛りのある整備地区を管網配管 する場合に溜池がパイプラインによって連結する ことになるため, 整備地区内の池掛りを統合でき る水路施設条件は满たされても，現状では統合の
動機がなく，池掛り統合の将来構想をもちつつ も，当面は旧来の池掛りのまま維持管理を存続さ せる場合がある。

（4）中山間地域の用水源問題

石井集落の用水源問題について，池掛りの統合 では香川用水の導水を前提にしたものではなかっ た。統合される池掛りが 2 haと小規模であったた め，その用水源は減歩分で確保できると考えたた めであった。

しかし，中山間地域の用水源問題については次 のように指摘されている4)。すなわち中山間地域 の水利条件は地形条件の制約により，一般に流域 が狭小なため, 中山河川, 渓流, 溜池等の集水 貯留機能は乏しく，また複数の水源あるいは，種 別の異なった水源に依存しなければならず，用水 系統およびその運用管理は複雑化している。用水 の絶対不足を補うためには，水源の拡充，用水の 有効利用の面から次のような方策が採られる場合 が多い。(1)水路を用排兼用水路として極力反復利 用を図る。(2)排水・雨水を中間および末端最下流 に設けた貯水池, ファームボンドに導き再利用を 図る。(3)用水のパイプライン化により，損失水量 の軽隇を図る。(4)既存溜池のカサ上げ，異なる水 源間での弾力運用, 地下水および湧水の積極的利 用を図る。

このように, 中山間地域の用水源は今まで述べ てきたような溜池ばかりでなく，種別の異なる水 源も共存しており，用水源開発の方策も多面的に 検討されなければならない。

ここで，溜池とは異なる用水源も問題にしなけ ればならないが, 池掛りは水掛りとも呼ばれてお り，本稿では溜池掛りのみを池掛りと呼ぶことに 限定し，水掛りは広義に考え，池掛りも含めて， 特定の用水源施設に着目した呼称, たとえば, 井 堰掛り，横井戸掛り，深井戸掛り，ポンプ掛り等 々の総称として用いることにする。

さて, 異なる水掛り間には用水量, 水利費等の 水利条件に格差があるのが一般的であり，娄場整 備でもこの水利条件差をどの程度解消できるか が, 整備後の水掛りの在り方に関係してくる。そ のために，用水源の開発方策を講じなければなら 
ないが, その場合に開発する用水源の受益地区を どの水掛り地区にするかが水掛りの再編とからん で問題となる。

たとえば，異なる水掛りがあっても，集落の属 地領域よりも水掛りが小さく，小规模な井堰掛り で番水をしているような場合には，集落の属地領 域で水掛りを統合する場合がある，この場合に は，前述した池掛りの統合と全く同様の動機が働 いている。

しかし，水掛りが集落の属地領域より小さくて も，用水源の開発が極度に進んでいるような地区 で，用水源の開発も見込めない場合とか，水利条 件差が著しい地区では，水脚りは統合することが なく，旧来の水掛りが整備後も復元される。

\section{4. 水掛りの再編と土地利用計画}

石井集落では整備後ブロックローテーションに よる集団転作を始めており，裏作あるいは施設栽 培のために溜池用水も通年使用を認めるようにな ク，耕地の利用率も整備前より高くなっている。

石井集落における池掛りの統合の意義は, 集落 レベルでみた場合，耕作区域と池掛りが調整さ れ，集落の属地領域に一致させたことにある。石 井ではそれを生かして全面的な集落営農を展開し ているわけではないが, 将来における耕地の集団 的利用を水利用の側面からも可能にする条件整備 であったとみることができる。すなわち，水利用 を面的にとらえて，土地利用と調整していくこと の意義を石井集落の事例は示している。

戋場整備の遅れている中山間地域において, 今 後高度な土地利用を展開する農業を考えると, 土 地利用計画の課題は一定のまとまりある流域を計 画対象領域として, 水掛り地区の再編を媒介項に して，土地利用の再編を考えていくべきではない だろうか。水掛り地区を媒介項にすることによっ $て$, 末端の維持管理組織や営㖘組織の水利用桠想 を土地利用計画に反映させることができるのでは ないだろうか。この土地利用計画に基づいて围場 整備がなされるべきであると考える。将来性のあ
る嘎場整備をするためにもこの土地利用計画の作 成は必須と考える。

ところで，今日中山間地域は「景観資源の活 用，地域の特性を生かした自然資源活用型高付加 価値晨業の展開, 加えて, 都市生活と農村空間と の融合を図るリゾート空間の創出，個性と安らぎ に満ちた生活環境」等の多用な機能を備えるた めの地域整備が期待され，まさしく農村計画的対 応が迫られているが，圑場整備が地域整備の役割 をになっている点からみても，水掛り地区を媒介 項とする土地利用計画の作成が核となって農村計 画は展開する必要がある。

\section{5. おわりに}

今日の農業をめぐろ様々な見解の中に農業形態 を企業的農業とそれ以外の農業に分けて考え，土 地利用型農業においてもその考えが農地の利用区 分に反映している。企業的農業をめざして平地農 村においては大区画の圃場整備が進められようと しているが，河川潅溉地域においても，水利用を 面的にとらえて土地利用との調整を図り，それを 土地利用計画に反映させていく方法は有効である と思われる。

溜池地域の事例を通して，農用地を確保し，整 備・保全していくためには，地域の立地条件に応 じて発展させてきた農業水利を面的にとらえて土 地利用と調整し，それを土地利用計画に汲み上げ る必要性を痛感している。

\section{引用文献}

1 ）農業土木学将来ビジョン検討委員会：豊かで美 しい国土・農村空間の創出, 農土学会, p. i, 12 . 48, 61，63，(1989)

2 ）玉城哲：水の思想，論争社，p. 25，(1979）

3 ) 山岡和純：中山間地域の活性化と農村整備, 農 土誌58(1)，p. 10，(1990)

4 ）岩崎和己・中達雄：中山間地带の水利構造物の 水利特性，農土誌 $55(1) ，$ p. 37，(1987）

5 ) 前出1), pp. 13-14 